\title{
Effect of BFRP Grid on Crack Propagation of Reinforced Concrete Beam with Thick-Cover Concrete
}

\author{
Hua-nan He and Li-juan Cheng \\ State Key Laboratory of Coastal and Offshore Engineering, Dalian University of Technology, China
}

\begin{abstract}
For the purpose of solving the problem of large crack width in concrete beam with thick cover, BFRP grid is added to the concrete cover to control the crack development and to improve the distribution status of cracks. In this paper, the bending tests under four-point loading are adopted to investigate cracking properties of reinforced concrete beams with thick cover, in which BFRP grid is added. During test cracking load, crack width and the number of crack were recorded, which will be analysed later. Test results show that crack development of reinforced concrete beam with thick cover can be effectively controlled, and the number of cracks was increased appearing tiny and dense cracks in structure, meanwhile maximum crack width was decreased, which can meet the requirements of engineering for crack control. In addition, BFRP grid has no effect on the cracking load of the structure and can slightly increase the ultimate bearing capacity.
\end{abstract}

\section{INTRODUCTION}

As is well known, reinforced concrete structures usually service in cracking because of low tensile strength of concrete (Huanan \& Chengkui, 2008). A lot of exposure tests show that the corrosion of reinforcement is related to the thickness of the concrete (Cao, Cheung, \& Chan, 2013; Lingjiang, 2007). Increasing the thickness of the concrete cover can improve the bond-anchorage properties, durability, and fireproof performance. Therefore, the reinforced concrete structures working in humid environment or severe environment are designed with thicker covers. However, the thicker the cover is, the greater the crack width is (Shilang \& Shiping, 2010). For the purpose of improving cracking properties of concrete cover, since geometry dimension of the concrete cover is small, it can be considered that adding fiber grid materials in the concrete cover, which can limit crack growth with steel bars under the working load (Xu \& Cai, 2009). In this paper, the BFRP with high tensile strength, corrosion resistance, light weight, and low cost is used as the limiting material (Cosenza, Manfredi, \& Realfonzo, 1997). Experimental study on cracks in six reinforced concrete beams with thick cover are carried out to investigate the crack development, crack distribution, and crack width of concrete beams laid BFRP grid in concrete covers.

\section{EXPERIMENTAL PRO}

A total of six reinforced concrete beams test were carried out, and the detailed size of the specimens are shown in Table 1. Among them, L-1-1 and L-2-1 beams are ordinary reinforced concrete beams without BFRP grid and other four beams are reinforced concrete beams with BFRP grid of different mesh sizes. The four-point loading method was used. Distance between one support and the end of specimen is $200 \mathrm{~mm}$ and reinforced concrete beam was loaded with $500 \mathrm{~T}$ oil pump. A transformation beam is arranged between the sensor and the beam, so that the concentrated load can be transferred to

Table 1. Specimens parameters.

\begin{tabular}{|c|c|c|c|c|c|c|c|c|}
\hline No. & $\begin{array}{c}\text { Length } \\
(\mathrm{mm})\end{array}$ & $\begin{array}{c}\text { Section } \\
\text { size }\left(\mathrm{mm}^{2}\right)\end{array}$ & $\begin{array}{c}\text { Cover } \\
\text { thickness } \\
(\mathrm{mm})\end{array}$ & $\begin{array}{l}\text { Side cover } \\
\text { thickness } \\
\text { c1 }(\mathrm{mm})\end{array}$ & $\begin{array}{l}\text { longitudinal } \\
\text { reinforcement }\end{array}$ & Stirrup & $\begin{array}{c}\text { FRP } \\
\text { grid size } \\
(\mathrm{mm})\end{array}$ & $\begin{array}{c}\text { FRP position } \\
\text { (from the bottom } \\
\text { of the beam) }(\mathrm{mm})\end{array}$ \\
\hline Beam L-1-1 & 3000 & $150 \times 300$ & 40 & 30 & $2 \Phi 18$ & Ф8@100 & I & I \\
\hline Beam L-1-2 & 3000 & $150 \times 300$ & 40 & 30 & $2 \Phi 18$ & Ф8@100 & 10 & 20 \\
\hline Beam L-1-3 & 3000 & $150 \times 300$ & 40 & 30 & $2 \Phi 18$ & Ф8@100 & 5 & 20 \\
\hline Beam L-2-1 & 3000 & $150 \times 300$ & 60 & 30 & $2 \Phi 18$ & Ф8@100 & I & I \\
\hline Beam L-2-2 & 3000 & $150 \times 300$ & 60 & 30 & $2 \Phi 18$ & Ф8@100 & 10 & 30 \\
\hline Beam L-2-3 & 3000 & $150 \times 300$ & 60 & 30 & $2 \Phi 18$ & Ф8@100 & 5 & 30 \\
\hline
\end{tabular}


the two-point loads. During the test, the cracking load, crack spacing, crack distribution, and crack width of specimens were recorded. The loading condition of specimen is shown in Figure 1.

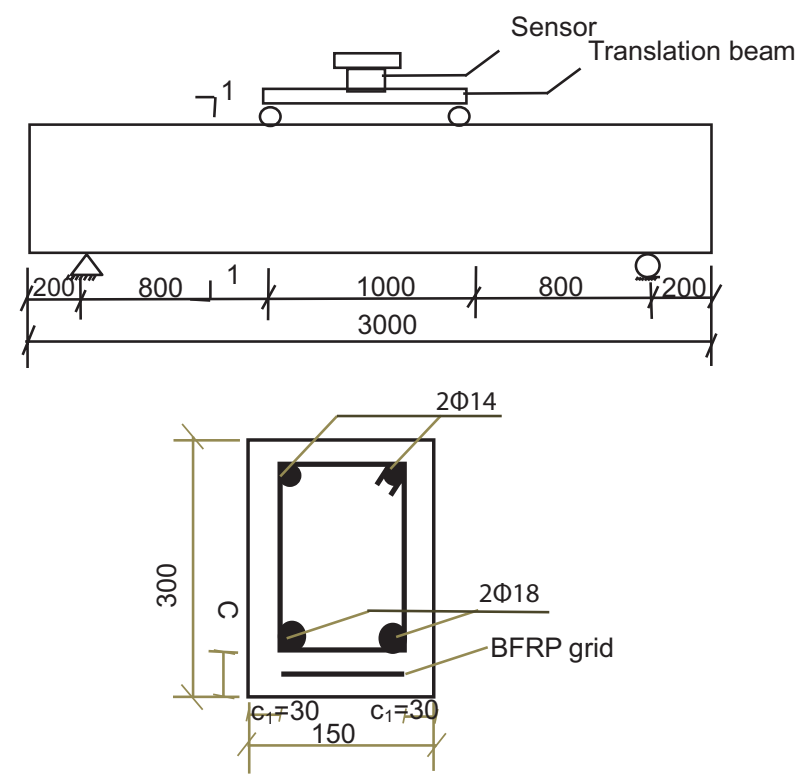

Figure 1. Loading diagram of bending beam.

Test material: cement 42.5 is used, the maximum size of the crushed stone is $15 \mathrm{~mm}$, and the sand ratio is $32 \%$. Concrete mix proportion is shown in Table 2. Before the experiment, the concrete cube specimens were tested for compressive strength, and the average cube compressive strength was $33.63 \mathrm{MPa}$. In the experiment, the diameter of reinforcement HRB335 is $18 \mathrm{~mm}$, and the average tensile yield strength is $380.2 \mathrm{MPa}$.

Table 2. Concrete mix proportion.

\begin{tabular}{ccccc}
\hline w/c & $\begin{array}{c}\text { Water } \\
\left(\mathbf{k g} / \mathbf{m}^{3}\right)\end{array}$ & $\begin{array}{c}\text { Cement } \\
\left(\mathbf{k g} / \mathbf{m}^{3}\right)\end{array}$ & $\begin{array}{c}\text { Sand } \\
\left(\mathbf{k g} / \mathbf{m}^{3}\right)\end{array}$ & $\begin{array}{c}\text { Stone } \\
\left(\mathbf{k g} / \mathbf{m}^{3}\right)\end{array}$ \\
\hline 0.46 & 220 & 478 & 541 & 1161 \\
\hline
\end{tabular}

The elastic modulus of BFRP is $100 \mathrm{GPa}$, and the tensile strength is $4500 \mathrm{MPa}$. The BFRP grid in the test was made by plain weave and was immersed in epoxy resin adhesive, then was treated with sand sticking in order to enhance the friction and bond strength between the fiber and the concrete.

For the reinforced concrete beams with BFRP grid in the concrete cover, the first step was to mark the location of the BFRP grid in timber form, and then to pour concrete to the marked position. The BFRP grids with different mesh sizes were set here, and then continued pouring concrete to the top of the formwork.
After demolded, all specimens were cured in water for 1 week, and removed from water to be kept in air.

The test was carried out on the 500-T hydraulic test machine. Before the cracks appeared, the load of each level was $5 \mathrm{kN}$; after the cracks appeared, each load level changed to be $3 \mathrm{kN}$. Each level sustained $2 \mathrm{~min}$ to ensure the deformation of the bending beam sufficiently. After each loading, the development of the crack was observed, and the width of crack was measured with the DJCK-2 crack width gauge (accuracy of $0.02 \mathrm{~mm}$ ). After the crack developed relatively greater, specimens were loaded to failure directly instead of loading step by step.

\section{TEST RESULTS AND ANALYSIS}

\subsection{Cracking load}

From the experimental results, the average cracking load of Series L-1 beams is $25.5 \mathrm{kN}$. The average cracking load of Series L-2 beams is $19.83 \mathrm{kN}$, which is reduced by $22.2 \%$ compared with Series $L-1$ ones. The increase of cover thickness results in the cracking load decreasing slightly. The cracking load is shown in Figure 2.

In same concrete cover, the cracking load of the reinforced concrete beams with or without BFRP is almost same.

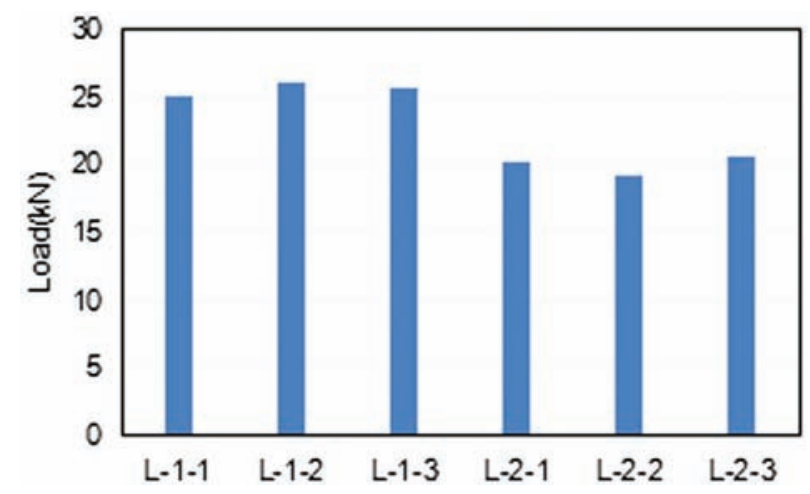

Figure 2. Cracking load histogram.

Thus, adding BFRP grid in the reinforced concrete beams has no significant influence on the cracking load. This is because the cracking of the reinforced concrete beam depends on the ultimate tensile strain of concrete.

\subsection{Crack distribution and crack width}

In this paper, we select Beam L-2-1 and Beam L-2-3 from six beams to compare and analyze cracks in detail.

The crack distribution diagram of the specimen is shown in Figure 3. It shows that there are seven cracks 
in the pure bending area of Beam L-2-1 in the ultimate limit state. Meanwhile, the Beam L-2-3 appeared 10 cracks, and the spacing between the cracks became smaller and the cracks distributed more evenly.
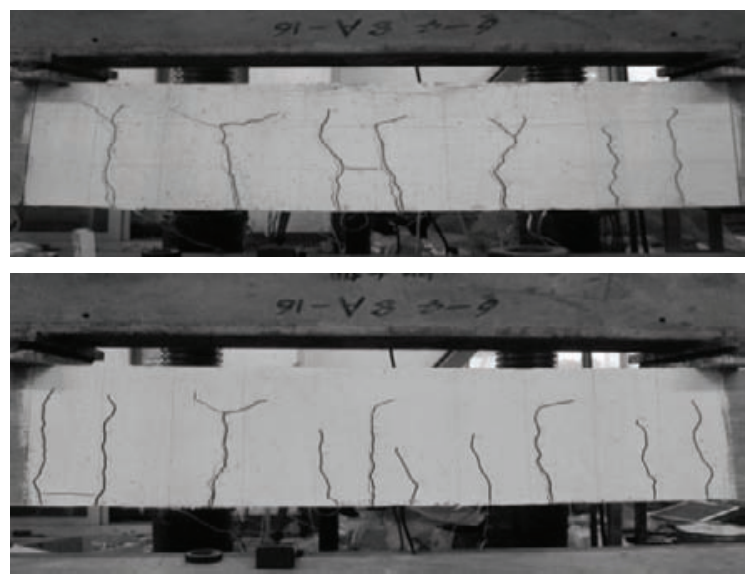

Figure 3. Crack distribution diagram of L-2-1 and L-2-3 (from up to down).

Normally, we study the width of cracks under serviceability limit state. And the flexural moment of the cross-section of the reinforced concrete bending member under normal use is approximately $50-70 \%$. The ultimate bearing capacity of Beam L-2-1 and Beam L-2-3 are 115 and $120 \mathrm{kN}$, respectively, and that of serviceability limit state are $57.5-80.5$ and 60 $84 \mathrm{kN}$.

When the load was $54 \mathrm{kN}$, the maximum crack width of Beam L-2-1 was $0.2 \mathrm{~mm}$ and that of Beam L-2-3 was $0.12 \mathrm{~mm}$, which was far less than the maximum crack width limit of $0.2 \mathrm{~mm}$ provided by "Code for design of concrete structures" (50010-2010 GB) (State Regulations of the People's Republic of China, 2010).

When the load was $57 \mathrm{kN}$, the maximum crack width of Beam L-2-1 was $0.22 \mathrm{~mm}$, which exceeded the maximum crack width limit; the maximum crack width of Beam L-2-3 was $0.16 \mathrm{~mm}$, which was lower than the maximum crack width limit.

When the load was $71 \mathrm{kN}$, the maximum crack width of Beam L-2-1 was $0.26 \mathrm{~mm}$, and that of Beam L-2-3 reached the maximum crack width limit $0.2 \mathrm{~mm}$.

When the ultimate limit state was satisfied, the bearing capacity of Beam L-2-3 was increased by $31.5 \%$ than that of Beam L-2-1. It indicated that BFPR grid has a great effect on controlling the crack development of reinforced concrete structure. Based on the test results, the maximum cracks of the both beams occurred in the second cracks. Therefore, this paper focuses on the analysis of the crack width of the first crack and the second crack, as shown in Figures 4 and 5 . From the graph, the crack growth rate of Beam L-2-1 was very fast. And when the load reached $100 \mathrm{kN}$, crack expanded rapidly and the maximum crack width reached $1.6 \mathrm{~mm}$. Crack propagation speed of Beam L-2-3 was slow without sudden increase and the maximum crack width was only $0.4 \mathrm{~mm}, 81.25 \%$ lower than that of Beam L-2-1.

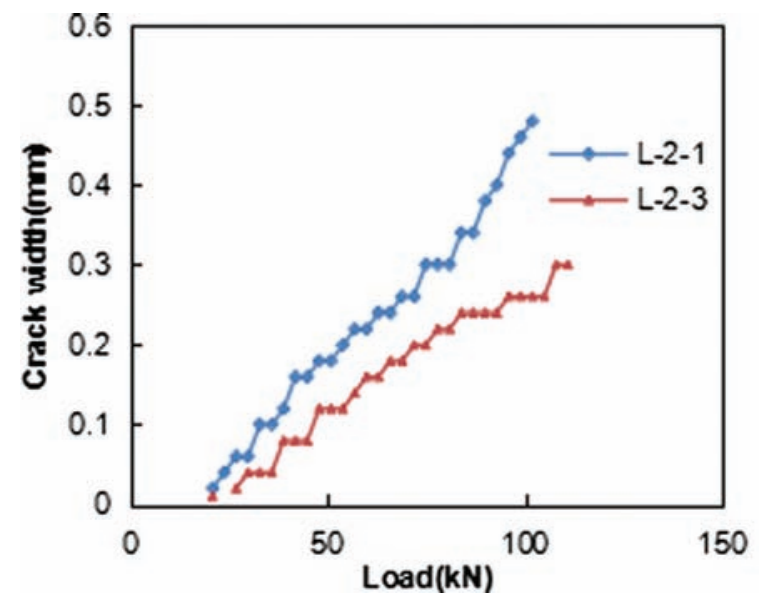

Figure 4. Crack width line of the first crack.

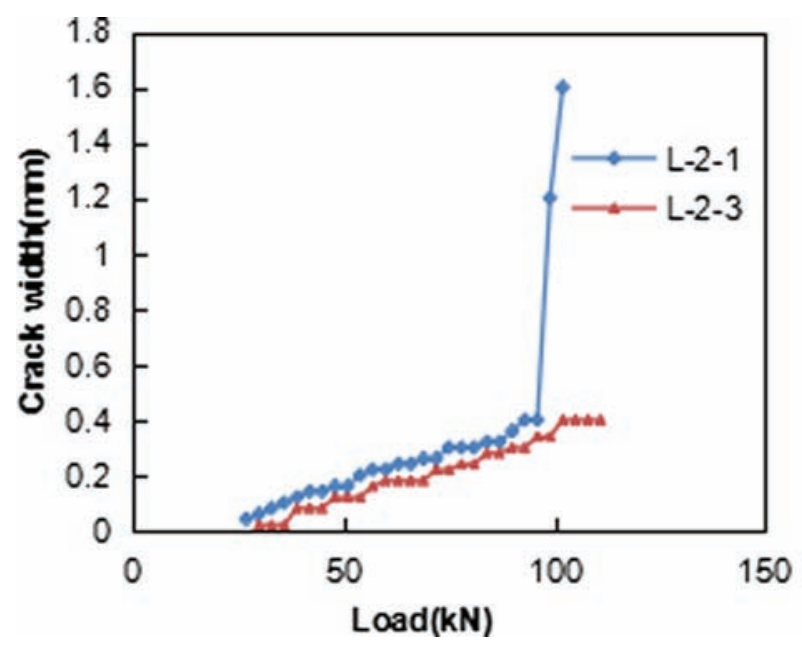

Figure 5. Crack width line of the second crack.

Hence, adding BFRP grid into concrete cover of reinforced concrete beams with thick-cover concrete can greatly limit cracks propagation, reduce crack width, and increase the number of cracks. These "dense and fine cracks" meet the engineering requirements on crack controlling.

This is because there is certain adhesive friction between the BFRP grid and concrete, and the direction of crack propagation is perpendicular to the direction of the BFRP net (Zhixing, 2005). When the concrete cracks, it can effectively limit the further expansion of concrete cracks due to the effect of adhesive friction, which plays a role of crack resistance. 


\subsection{Bearing capacity analysis}

Analysis of the test results shows that the yield load and ultimate load of Series L-1 beams are larger than those of Series L-2 beams, namely, with an increase in the thickness of the concrete cover, the bearing capacity of the reinforced concrete beam is reduced. Analysis and comparison of Series L-1 of beams show that yield load and ultimate load of reinforced concrete beams with BFRP grid increases slightly, but the improvement is not obvious. Series L-2 beams have the same conclusion. Flexural bearing capacity of beams is shown in Figure 6.

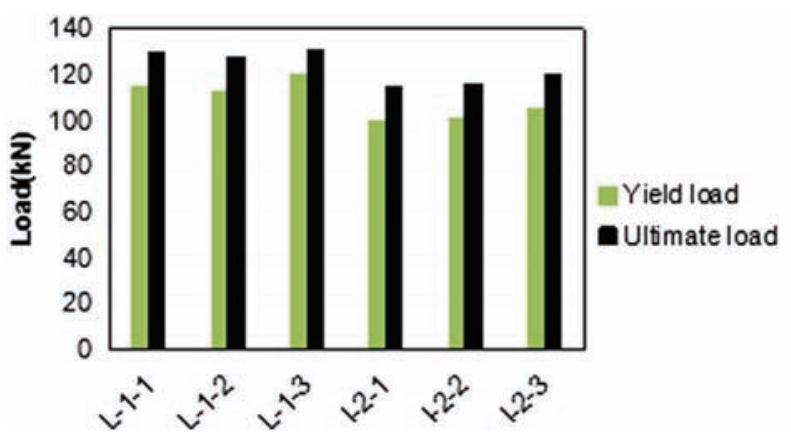

Figure 6. Histogram of flexural bearing capacity.

\section{CONCLUSION}

Adding BFRP grids into reinforced concrete beams with thick-cover concrete can greatly control the crack propagation and reduce the maximum crack width and average crack width. At the same time, the crack spacing tends to even and the number of cracks is increased, which can satisfy the requirement of engineering for crack control.

Adding BFRP grid has no influence on the cracking load of reinforced concrete beams with thickcover concrete. It is not considered the anti-crack performance of BFRP grid in design.
Adding BFRP grid into reinforced concrete beams with thick-cover concrete may slightly increase yield load and ultimate load. And with the size of the BFRP grid becomes smaller, the bearing capacity is improved.

\section{REFERENCES}

Cao, C., Cheung, M. M. S., \& Chan, B. Y. B. (2013). Modelling of interaction between corrosioninduced concrete cover crack and steel corrosion rate. Corrosion Science, 69, 97-109.

Cosenza, E., Manfredi, G., \& Realfonzo, R. (1997). Behavior and modeling of bond of FRP rebars to concrete. Journal of Composites for Construction, 1(2), 40-51.

Huanan, H., \& Chengkui, H. (2008). Calculation of crack width of concrete pressure pipe steel lined steel fiber reinforced self stressing. Journal of Hydraulic Engineering, 08, 988-993.

Lingjiang, Y. (2007). Cracking process of concrete protective layer caused by corrosion of steel bars and analysis of its influencing factors. Zhejiang University, Zhejiang, China.

Shilang, X., \& Shiping, X. (2010). Textile combined steel reinforced concrete beam flexural behavior analysis theory. Science in China Science and Technology, 06, 619-629.

State Regulations of the People's Republic of China. (2010). Code for Design of Concrete structures GB50010-2010. Beijing, China: China Building Industry Press.

Xu, S., \& Cai, X. (2009). Experimental study on mechanical properties of ultra-high toughness fiber reinforced cementitious composite. Journal of Hydraulic Engineering, 9, 5.

Zhixing, Z. (2005). Study on steel fiber reinforced concrete cracks based on fracture mechanics. Industrial Architecture, 3, 53-55. 